\title{
Comparison of ASBR and CSTR reactor for hydrogen production from palm oil mill effluent under thermophilic condition
}

\author{
Jiravut Seengenyoung ${ }^{1}$, Sompong O-Thong ${ }^{2,3}$, Poonsuk Prasertsan ${ }^{1,4}$ \\ ${ }^{1}$ Department of Industrial Biotechnology, Faculty of Agro-Industry, Prince of Songkla University, Songkhla, Thailand \\ ${ }^{2}$ Department of Biology, Faculty of Science, Thaksin University, Phatthalung, Thailand \\ ${ }^{3}$ Microbial Resource Management Research Unit, Faculty of Science, Thaksin University, Phatthalung, Thailand \\ ${ }^{4}$ Palm Oil Products and Technology Research Center (POPTEC), Faculty of Agro-Industry, Prince of Songkla University, Songkhla, \\ Thailand \\ Email:poonsuk918@yahoo.com
}

Received 28 November 2013; revised 31 December 2013; accepted 21 January 2014

Copyright (C) 2014 Jiravut Seengenyoung et al. This is an open access article distributed under the Creative Commons Attribution License, which permits unrestricted use, distribution, and reproduction in any medium, provided the original work is properly cited. In accordance of the Creative Commons Attribution License all Copyrights (C) 2014 are reserved for SCIRP and the owner of the intellectual property Jiravut Seengenyoung et al. All Copyright (C) 2014 are guarded by law and by SCIRP as a guardian.

\section{ABSTRACT}

Hydrogen production from palm oil mill effluent (POME) by Thermoanaerobacterium thermosaccharolyticum PSU-2 was investigated both in batch and continuous reactors using anaerobic sequencing batch reactor (ASBR) and continuous stirred tank reactor (CSTR). The hydrogen production determined from batch experiment of POME at an inoculum size of $0 \%, 10 \%, 20 \%$ and $30 \%(v / v)$ was $161,201,246$ and $296 \mathrm{~mL} \mathrm{H}_{2} / \mathrm{g}$-COD with COD removal efficiency of $21 \%, 23 \%, 23 \%$ and $23 \%$, respectively. Continuous hydrogen production was start-up with $30 \%$ (v/v) inoculum in both ASBR and CSTR reactors and more than $30 \%$ COD removal could be obtained at HRT of 4 days, corresponding to OLR of $11.3 \mathrm{~g}$ COD/ $L \cdot d a y$. Similar hydrogen production rates of 2.05 and $2.16 \mathrm{~L}_{\mathrm{H}_{2}} / \mathrm{L}$. day were obtained from ASBR and CSTR, respectively. COD removal efficiency of ASBR was $\mathbf{3 7 . 7 \%}$, while it was $\mathbf{4 4 . 8 \%}$ for CSTR. However, ASBR was stable in term of alkalinity, while the CSTR was stable in term of hydrogen production, soluble metabolites concentration and alkalinity. Therefore, the CSTR was found to be more stable in hydrogen production than ASBR under the same OLR.

\section{KEYWORDS}

Thermoanaerobacterium thermosaccharolyticum PSU-2; Hydrogen Production; Palm Oil Mill Effluent; Thermophilic Fermentation

\section{INTRODUCTION}

Hydrogen $\left(\mathrm{H}_{2}\right)$ is a clean and promising fuel when it is ultimately derived from renewable energy sources. It has high energy content, and water is the sole end product after combustion [1]. Hydrogen production by microorganisms can be divided into two main categories: one involves the use of photosynthetic bacteria and algae under light condition and the other, anaerobic fermentative bacteria under dark condition. Dark fermentative production of hydrogen can convert often negative valued organic wastes into hydrogen-rich gas [2-5]. Thermophilic bacteria are therefore considered as most promising microorganisms than mesophilic bacteria for $\mathrm{H}_{2}$ production. A strict anaerobic thermophilic bacterial strain with high production rate and yield of $\mathrm{H}_{2}$, named Thermoanaerobacterium thermosaccharolyticum PSU-2, was isolated from palm oil mill effluent (POME) by O-Thong et al. [1]. The microbial community during hydrogen production from POME using anaerobic sequencing batch reactor (ASBR) at high temperature was dominated by Thermoanaerobacterium spp. that included close relatives of $T$. thermosaccharolyticum, $T$. aotearoense and uncultured Thermoanaerobacterium [1]. $\mathrm{C} / \mathrm{N}$ ratio and iron concentration have a significant interactive effect on the hydrogen production ability of the Thermoanaerobacterium-rich sludge [2]. One of the factors affecting the yield and the rate of hydrogen formation by dark fermentation is the composition of the bacterial culture. The use of pure cultures in dark fermentation of carbohydrates for hydrogen production is expensive and technically difficult requiring sterile conditions 
and strict control of environmental conditions [6]. Among the various approaches to increasing hydrogen production yield from organic wastes, the nutrient supplementation appears promising. Nutrient supplementation improved simultaneous hydrogen production and pollution reduction from POME using thermophilic fermentation. T. thermosaccharolyticum was the dominant hydrogen producing microorganisms in this fermentation [7]. Bioaugmentation is the practice of adding specific microorganisms to a system to enhance a desired activity [8]. This increases the population of bacteria after upsets from uncontrolled biomass loss, fluctuations in $\mathrm{pH}$, toxic events, or temperature decrease [8] and degradation of specific substrates [9]. For anaerobic fermentation, bioaugmentation has been investigated at laboratory scale to improve start-up of new digesters [10]. The economics value as a result of this study was the optimum inoculums concentration for start-up culture. Output from the by-product was acid metabolism, such as acetic acid and butyric acid. ASBR was employed for fermentation of hydrogen from palm oil mill effluent (POME) and nutrient-supplemented POME for substrate gave the hydrogen production rate of $4.4 \pm 0.38 \mathrm{LL}^{-1} \cdot \mathrm{d}^{-1}$ and $6.1 \pm$ $0.03 \mathrm{LL}^{-1} \cdot \mathrm{d}^{-1}$, respectively [7]. Moreover, biohydrogen production is usually conducted via continuous flow stirred tank reactors (CSTR) because they are easy to operate and can provide a good substrate-biomass contact by vigorous mixing [11]. Of all information, there is a possibility to use POME for hydrogen production by using $T$. thermosaccharolyticum PSU-2 as start-up inoculums (bioaugmentation) and used ASBR and CSTR for operation in the experiment.

In this study, batch experiment focused on finding the optimum inoculums size for hydrogen production potential and COD removal and compared the performance of ASBR and CSTR operation on hydrogen production stability and COD removal for long time operation. In addition, the metabolite characteristics from hydrogen production was also determined.

\section{MATERIALS AND METHODS}

\subsection{Inoculum and POME}

The thermophilic fermentative bacterium Thermoanaerobacterium thermosaccharolyticum PSU-2, previously isolated by O-Thong et al. [3], was used for the inoculums preparation in this experiment. The basal anaerobic medium (BA medium) was prepared as previously described [12]. The medium was flushed with nitrogen gas for $20 \mathrm{~min}$ to obtain completely anaerobic conditions. The $\mathrm{pH}$ of medium was adjusted to 5.5 by adding $1 \mathrm{M}$ $\mathrm{NaOH}$ or $1 \mathrm{M} \mathrm{HCl}$. Cell suspension of $10 \mathrm{ml}$ from cultivation at $60^{\circ} \mathrm{C}$ at exponential growth phase (OD660 0:5) [1] was transferred into $90 \mathrm{~mL}$ supplemented BA me- dium and cultured another round, After that, the microbial suspension was used as the experiment inoculums. The culture was stored in a refrigerator and subcultured once a month. The purity of this culture was routinely checked under the microscope.

POME was collected from the receiving tank of Labtavee Palm Oil Co., Ltd. in southern Thailand. It had the following characteristics: high temperature $\left(60^{\circ} \mathrm{C}-85^{\circ} \mathrm{C}\right)$, $4.6 \mathrm{~g}$ oil $\mathrm{L}^{-1}, 39.2 \mathrm{~g}$ total solids $\mathrm{L}^{-1}, 6 \mathrm{~g}$ suspended solids $\mathrm{L}^{-1}, 56.3 \mathrm{~g} \mathrm{COD} \mathrm{L}^{-1}, 1.5 \mathrm{~g}$ total nitrogen $\mathrm{L}^{-1}, 125 \mathrm{mg}$ total phosphorus $\mathrm{L}^{-1}, 8.3 \mathrm{~g}$ total carbohydrate $\mathrm{L}^{-1}, 589$

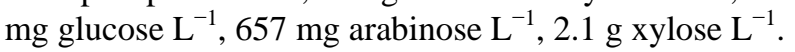

\subsection{Reactor Operation and Monitoring on ASBR}

The experiment using ASBR was setup. The reactor tank was made from a glass bottle with a total volume of $1 \mathrm{~L}$. The operating volume was $800 \mathrm{~mL}$. The reactor was run by intermittent mixed feeding at $200 \mathrm{rpm}$ and with $24 \mathrm{~h}$ cycles. Each cycle consisted of 30 min fill, 22 h 40 min reaction, 30 min settlement, 10 min draw and 10 min idle [7]. ASBR was operated at $60 \pm 1^{\circ} \mathrm{C}$, $\mathrm{pH}$ of $5.5 \pm 0.2$, 4-day HRT [3] and $11.5 \pm 0.2 \mathrm{gL}^{-1} \cdot \mathrm{d}^{-1}$ OLR. The inoculums T. thermosaccharolyticum PSU-2 of $240 \mathrm{~mL}$ $(30 \% \mathrm{v} / \mathrm{v}), 160 \mathrm{~mL}(20 \% \mathrm{v} / \mathrm{v})$ and $80 \mathrm{~mL}(10 \% \mathrm{v} / \mathrm{v})$ were fed into the ASBR using no addition of inoculums $(0 \%$ $\mathrm{v} / \mathrm{v}$ ) for control and fulfill nutrient-supplemented POME to $800 \mathrm{ml}$. The incubation was conducted for 4 days (batch experiment). After that, POME was then fed into the reactor at 0.21 cycle $^{-1} \cdot$ day $^{-1}$ to achieve a 4-day HRT. The steady-state condition was reached when hydrogen gas content, biogas volume and the volatile fatty acids (VFA) concentration in the effluent were stable (less than $10 \%$ variation) for a week [7]. The $\mathrm{pH}$ was maintained at 5.5 by adding $2 \mathrm{M} \mathrm{HCl}$ or $2 \mathrm{M} \mathrm{NaOH}$. The ASBR was routinely monitored for $\mathrm{pH}$, gas production and composition, total carbohydrate utilization, total alkalinity, COD removal, total solids, volatile solids and volatile organic acids.

\subsection{Reactor Operation and Monitoring on CSTR}

The experiment was carried out in a $4 \mathrm{~L}$ reactor with 2.5 $\mathrm{L}$ working volume of POME was used as substrate for the experiment. The reactor was operated at $60^{\circ} \mathrm{C}$ with a HRT of 4 days. The reactor was fed three times per day using a peristaltic pump (Watson Marlow). Inoculum from ASBR was used as start-up culture and operation was conducted for 30 days. The $\mathrm{pH}$ was maintained at 5.5 by adding $2 \mathrm{M} \mathrm{HCl}$ or $2 \mathrm{M} \mathrm{NaOH}$. The ASBR was routinely monitored for $\mathrm{pH}$, gas production and composition, total carbohydrate utilization, total alkalinity, COD reduction, total solids, volatile solids and volatile 
organic acids.

\subsection{Analytical Methods}

The volume of biogas was measured with a wet syringe and the composition was analyzed by gas chromatography (GC-8APT) with thermal conductivity detector (TCD), Shimadzu, Japan. The temperatures of the injection port, oven and detector were $100^{\circ} \mathrm{C}, 50^{\circ} \mathrm{C}$ and $100^{\circ} \mathrm{C}$, respectively. Argon as a carrier gas and the activated charcoal packed column were used for the analysis of biogas composition [13]. Liquid samples were taken from the culture at designated time intervals to analyze for the composition of soluble metabolites including $\mathrm{pH}$ and reducing sugar. The reducing sugar was determined by high performance liquid chromatography (HPLC), Aligent 1100. The hydrogen effluent was centrifuged at $12,000 \mathrm{~g}$ for $10 \mathrm{~min}$, then, the supernatant was filtered through a nitrocellulose membrane with $0.2-\mu \mathrm{L}$ pores. The apparatus of HPLC including a quaternary pump, a manual injector, a refractive index detector, an online vacuum degasser, a thermostatted column compartment, an Aminex HPX-87H ion exclusion column (300 mm $\times$ $7.8 \mathrm{~mm}$ ) (Bio-Rad, USA) and a ChemStation Software. Operation conditions were: $20 \mu \mathrm{L}$ sample volume; $5 \mathrm{mM}$ $\mathrm{H}_{2} \mathrm{SO}_{4}$ as a mobile phase; flow rate of $0.7 \mathrm{~mL} / \mathrm{min}$ and a column temperature of $65^{\circ} \mathrm{C}$. The total carbohydrate content was analyzed by the Anthrone method [10] Chemical oxygen demand (COD), total Kjeldahl nitrogen (TKN), and ammonium nitrogen and alkalinity were measured according to standard methods for the examination of water and wastewater [14]. Chemical oxygen demand (COD), $\mathrm{pH}$, total solids (TS), volatile solids (VS), volatile organic acids, total phosphorus and total Kjeldahl nitrogen (TKN) were determined in accordance with the procedures described in the Standard Methods [15]. The total carbohydrate content was analyzed by the anthrone method [16].

\section{RESULTS AND DISCUSSION}

\subsection{Effects of Inoculum Size on Hydrogen Production in Batch Fermentation}

The reactor in first batch reached stop produce hydrogen after 5 days. It was found that the inoculation of $T$. thermosaccharolyticum PSU-2 at 30\% gave the maximum hydrogen yield (Yp/s) of $296.14 \mathrm{~mL} / \mathrm{g}-\mathrm{COD}$ (Table 1) while inoculation at $10 \%$ and $20 \%$ gave the hydrogen yield of 201 and $246 \mathrm{~mL} / \mathrm{g}-\mathrm{COD}$, respectively. The experiments followed by heat-treated inoculums and no inoculums addition methods which gave the hydrogen yield of 269 and $258 \mathrm{~mL} / \mathrm{g}-\mathrm{COD}$, respectively. The hydrogen content was 41\%, 42\%, 39\%, 40\% and 44\%, respectively. COD was reduced by $23 \%$ in all methods. However, the inoculation of $T$. thermosaccharolyticum
Table 1. Comparative hydrogen production performance from various methods for preparing thermophilic hydrogen production seed in batch operation system (4 days).

\begin{tabular}{|c|c|c|c|c|c|}
\hline & & $0 \%$ & $10 \%$ & $20 \%$ & $30 \%$ \\
\hline Parameters & $\mathbf{H T}^{*}$ & PSU 2 & PSU 2 & PSU 2 & PSU 2 \\
\hline Initial $\mathrm{pH}$ & 5.6 & 5.6 & 5.6 & 5.5 & 5.5 \\
\hline Final $\mathrm{pH}$ & 5.4 & 5.3 & 5.3 & 5.4 & 5.4 \\
\hline $\mathrm{H}_{2}(\%)$ & 40.8 & 44.1 & 42.2 & 39.5 & 41.3 \\
\hline $\mathrm{N}_{2}(\%)$ & 11.8 & 5.7 & 7.7 & 10.4 & 6.1 \\
\hline $\mathrm{CH}_{4}(\%)$ & 0.00 & 0.00 & 0.00 & 0.00 & 0.00 \\
\hline $\mathrm{CO}_{2}(\%)$ & 47.9 & 50.2 & 50.1 & 50.1 & 52.6 \\
\hline $\mathrm{HY}\left(\mathrm{mLH}_{2} / \mathrm{gCOD}\right)$ & 269 & 258 & 201 & 246 & 296 \\
\hline Acetic acid (g/L) & 5.4 & 4.8 & 4.1 & 3.7 & 4.4 \\
\hline Butyric acid (g/L) & 4.5 & 4.7 & 4.5 & 4.3 & 3.8 \\
\hline Lactic acid (g/L) & 0.2 & 0.2 & 0.2 & 0.19 & 0.18 \\
\hline Formic acid (g/L) & 0.23 & 0.24 & 0.20 & 0.18 & 0.17 \\
\hline Propionic acid (g/L) & 0.69 & 0.69 & 0.65 & 0.60 & 0.55 \\
\hline Total alkalinity (g/L) & 2.8 & 3.2 & 2.3 & 2.7 & 2.1 \\
\hline TS $(\mathrm{g} / \mathrm{L})^{*}$ & 52 & 35 & 47 & 59 & 33 \\
\hline VS $(g / L)^{*}$ & 22 & 14 & 22 & 29 & 17 \\
\hline TSU (\%) ${ }^{*}$ & 53 & 53 & 51 & 57 & 60 \\
\hline TCU $(\%)^{*}$ & 81 & 80 & 78 & 82 & 84 \\
\hline COD removal (\%) ${ }^{*}$ & 23 & 23 & 23 & 23 & 23 \\
\hline
\end{tabular}

${ }^{*} \mathrm{HT}=$ Heat treatment inoculum, TS $=$ Total suspended solids, VS = Volatile solids, TSU $=$ Total sugar utilization, TCU $=$ Total carbohydrate utilization and COD removal $=$ Chemical oxygen demand reduction .

PSU-2 at 30\% was not cost effective for practical use in industry, although it gave acetic acid and butyric acid (4.4 and $3.8 \mathrm{~g} / \mathrm{L}$, respectively) as a major soluble metabolites. In addition, this experiment gave the total alkalinity, total suspended solids, volatile solids of $2.1 \mathrm{mg} / \mathrm{L}$, $33.8 \mathrm{~g} / \mathrm{L}, 17.9 \mathrm{~g} / \mathrm{L}$, respectively, with $60 \%$ total sugar utilization and $84 \%$ total carbohydrate utilization. The characteristics of the fermentation broth was similar to all other treatments.

\subsection{Hydrogen Production on ASBR Semi Continuous Operation}

The reactor in the first batch stopped producing hydrogen after 5 days cultivation. After that the system was operated steadily for a month in continuous operation at 4-day HRT. Before reaching steady state, fluctuations were observed in hydrogen production and other parameters. In the follow-up on long-term operation for hydrogen production, the experimental results showed the 
inconsistency of hydrogen production, because of the adaptation of culture process from batch system to semicontinuous mode. The addition of starter culture $T$. thermosaccharolyticum PSU-2 at $30 \%(\mathrm{v} / \mathrm{v})$ resulted in the production rate (average) of $2.1 \mathrm{LL}^{-1} \cdot \mathrm{d}^{-1}$ (Figure 1 ). However, in the follow-up long-term operation, hydrogen production was efficient during 5 - 11 days fermentation and decreased thereafter. This may be caused by the inhibition of by-products (product inhibition) of acetic acid and butyric acid [17]. These soluble metabolites (Figure 2) caused the decrease of $\mathrm{pH}$ during the high rate of hydrogen production. The amount of volatile acids formed in fermentation broth inhibited the microbial growth because it blocked the electron transfer processes of the cell [17], so that the hydrogen production rate was not stable. When monitoring the composition of the gas on long time operation, the hydrogen and carbon dioxide ratio was in the range of $45 \%-50 \%$ and
$50 \%$ - 55\%, respectively. The experiment did not produce methane. Hydrogen content was lower than that reported by O-Thong et al. [2] at $60 \%$.

\subsection{Hydrogen Production on CSTR Semi Continuous Operation}

The addition of starter culture $T$. thermosaccharolyticum PSU-2 at 30\% (v/v) in CSTR operation resulted in the production rate in the range of $2.0-2.3 \mathrm{LL}^{-1} \cdot \mathrm{d}^{-1}$ with the average of $2.16 \mathrm{LL}^{-1} \cdot \mathrm{d}^{-1}$. The production rate and other characteristics such as alkalinity and $\mathrm{pH}$ were rather stable throughout the long-term experiment (Figure 3), at $4.31 \mathrm{gL}^{-1}$ and 5.46 (average), respectively. The $\mathrm{pH}$ remained in the neutral range during the whole process due to the strong buffer capacity of the fermentation broth and suitable alkalinity. These $\mathrm{pH}$ and alkalinity values were in the same range as in previous reports $[13,18]$.

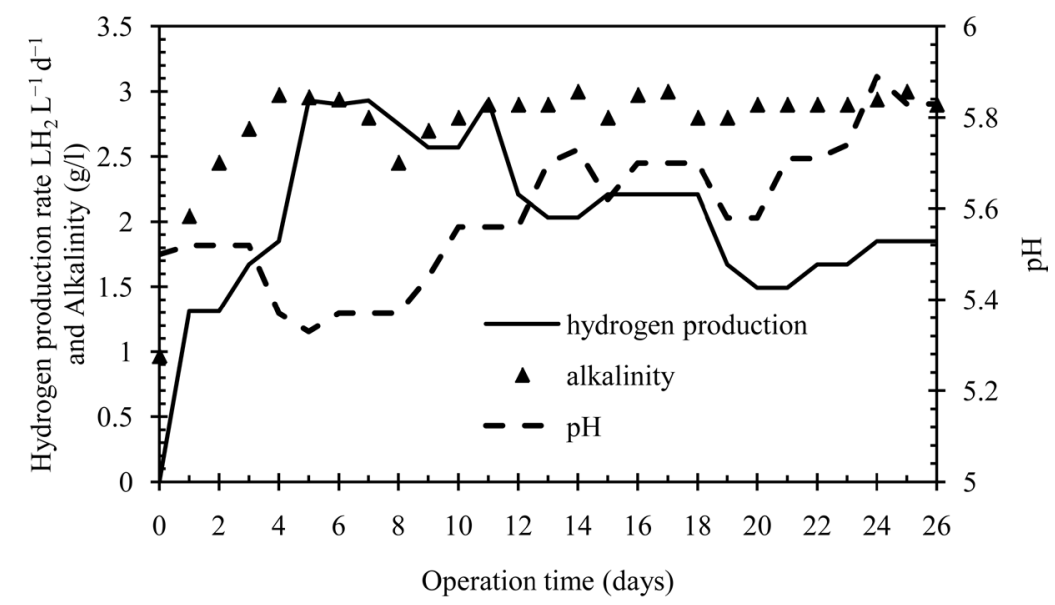

Figure 1. Time course of hydrogen production, $\mathrm{pH}$ and alkalinity during ASBR operation using $30 \%(\mathrm{v} / \mathrm{v})$ Thermoanaerobacterium thermosaccharolyticum as a start-up inoculum for hydrogen production from palm oil mill effluent.

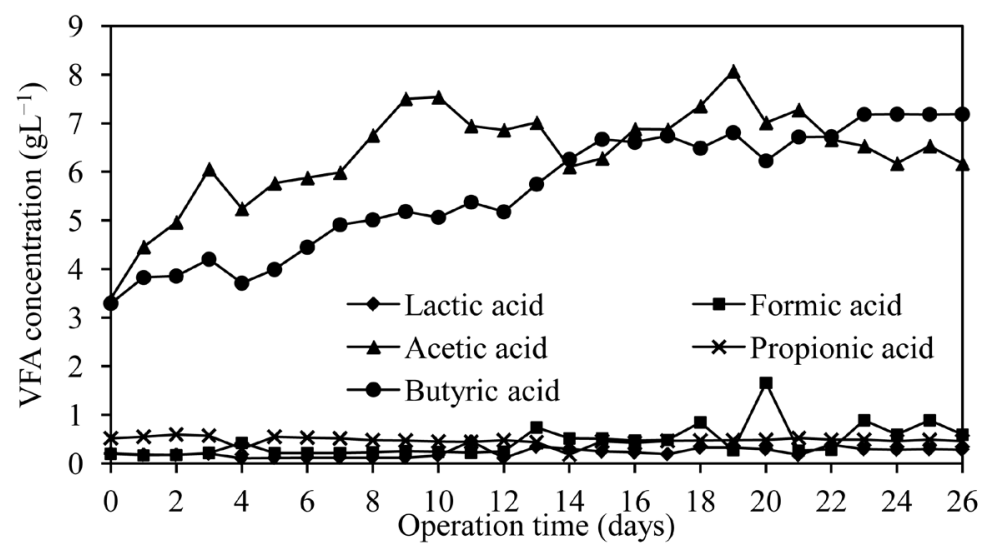

Figure 2. Time course of VFAs production during ASBR operation 30\% (v/v) Thermoanaerobacterium thermosaccharolyticum as a start-up inoculum for hydrogen production from palm oil mill effluent. 
Increased VFA production was observed and acetate was accumulated as the main product. Butyrate production was relative high, while lactic acid, formic acid and propionic acid production was low. At the $5^{\text {th }}$ day of operation, the acetate, and butyrate production was further increased and decreased afterwards (Figure 4), their concentration (average) was kept stable at the level of 7.44, 4.36, $0.33,0$ and $0.87 \mathrm{gL}^{-1}$ respectively, during the periods after $12^{\text {th }}$ day. VFAs values were higher than the previous reports $[13,17]$. VFAs production could lead to severe inhibition on hydrogen fermentation because the VFAs can stimulate, inhibit or become toxic to the fermentative bacteria [17]. These results indicated that the thermophilic temperature had a positive effect on the acidification of organic wastes and lead in an increased acetic acid and butyric acid production. Similar results were previously reported by O-Thong et al. $[13,19]$ and
Thomas et al. [20]. It has been reported that the formation of acetate and butyrate resulted in higher biohydrogen production which was evident in this study.

\section{CONCLUSION}

Bioaugmentation by adding $T$. thermosaccharolyticum PSU-2 at $30 \%(\mathrm{v} / \mathrm{v})$ can improve the hydrogen yields from 258.63 to $296.14 \mathrm{mLH}_{2} \cdot \mathrm{g}^{-1} \mathrm{COD}$. But the COD removal did not change when compared with the control and the other inoculation concentration. The ASBR operation was not stable in the long-term operation that was consistent with the inconsistent of $\mathrm{pH}$ in the fermentation broth. Acetic acid and butyric acid were accumulated in the fermentation broth and may result in the inhibition of hydrogen production. For thermophilic hydrogen fermentation of palm oil mill effluent, CSTR operation gave

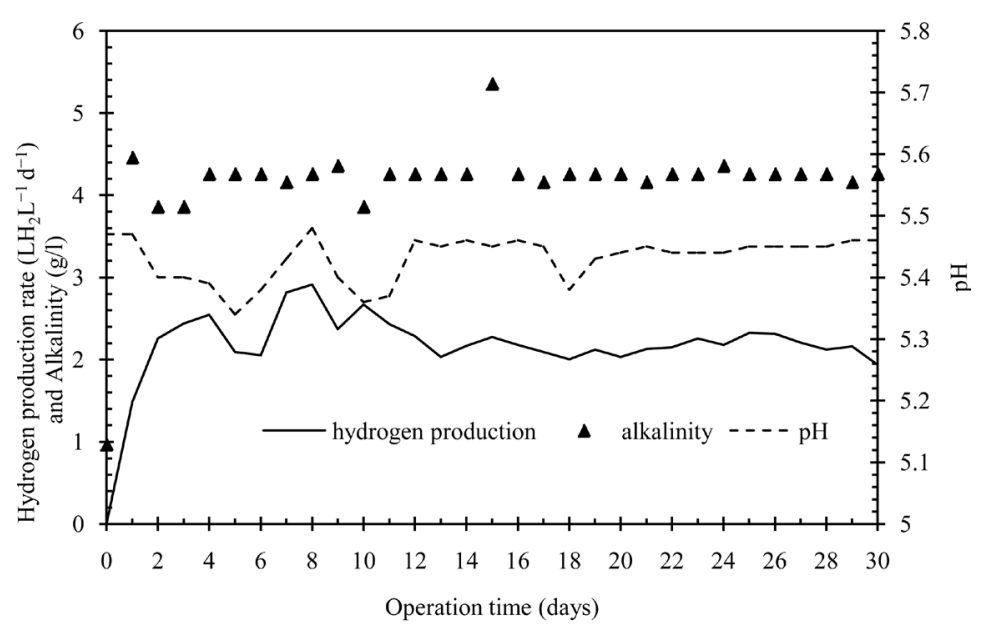

Figure 3. Time course of hydrogen production, $\mathrm{pH}$ and alkalinity during CSTR operation $30 \%(\mathrm{v} / \mathrm{v})$ Thermoanaerobacterium thermosaccharolyticum as a start-up inoculum for hydrogen production from palm oil mill effluent.

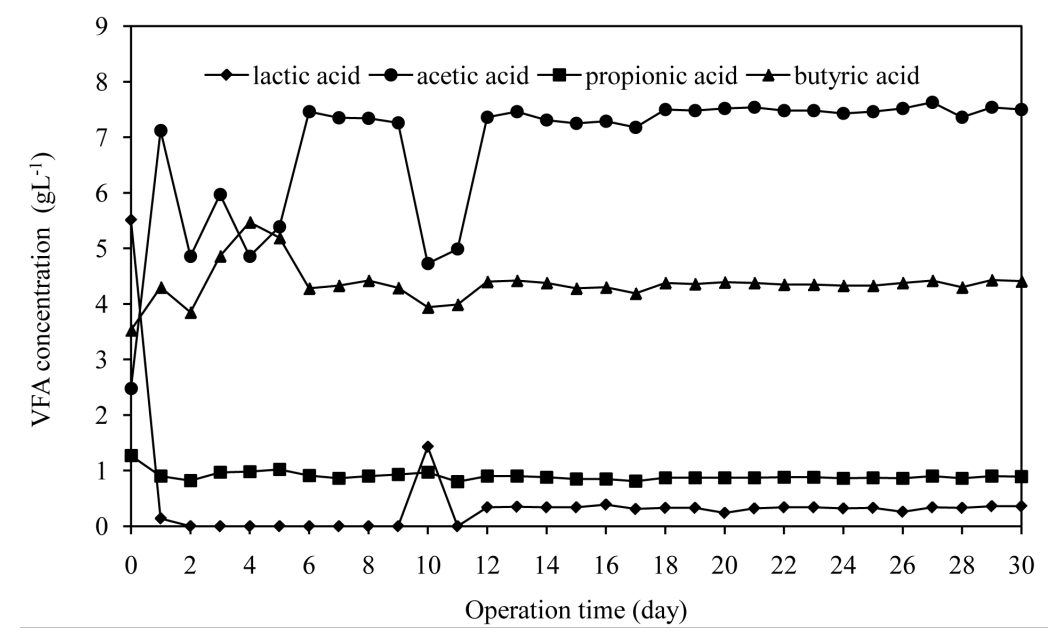

Figure 4. Time course of VFAs production during CSTR operation 30\% (v/v) Thermoanaerobacterium thermosaccharolyticum as a start-up inoculum for hydrogen production from palm oil mill effluent. 
the maximum hydrogen production rate of 2.16 $\mathrm{LL}^{-1} \cdot \mathrm{d}^{-1}$ and $44.7 \%$ COD removal. Characteristic of fermentation broth were relatively constant throughout the experiment such as $\mathrm{pH}$, alkalinity, acetic acid and butyric acid. All this indicated that the CSTR operation was suitable for themophilic hydrogen fermentation by palm oil mill effluent.

\section{ACKNOWLEDGEMENTS}

The work was under MEXT-ARDA Collaborative Project and financially supported by Agricultural Research Development Agency (ARDA) and Asia-Africa Science and Technology Strategic Cooperation Promotion Program. The authors would like to thank Palm Oil Products and Technology Research Center (POPTEC) for giving the scholarship to Mr. Jiravut Seengenyoung.

\section{REFERENCES}

[1] O-Thong, S., Prasertsan, P., Karakashev, D. and Angelidaki, I. (2008) Thermophilic fermentative hydrogen production by the newly isolated Thermoanaerobacterium thermosaccharolyticum PSU-2. International Journal of Hydrogen Energy, 33, 1204-1214. http://dx.doi.org/10.1016/j.ijhydene.2007.12.015

[2] O-Thong, S., Prasertsan, P., Intrasungkha, N., Dhamwichukorn, S. and Birkeland, N.K. (2008) Optimization of simultaneous thermophilic fermentative hydrogen production and COD reduction from palm oil mill effluent by Thermoanaerobacterium-rich sludge. International Journal of Hydrogen Energy, 33, 1221-1231. http://dx.doi.org/10.1016/j.ijhydene.2007.12.017

[3] O-Thong, S., Prasertsan, P. and Birkeland, N.K. (2009) Evaluation of methods for preparing hydrogen-producing seed inocula under thermophilic condition by process performance and microbial community analysis. Bioresource Technology, 100, 909-918.

http://dx.doi.org/10.1016/j.biortech.2008.07.036

[4] Nielsen, A.T., Amandusson, H., Bjorklud, R., Dannetun, H., Ejlertsson, J. and Ekedahl, L.G. (2001) Hydrogen production from organic waste. International Journal of Hydrogen Energy, 26, 547-550.

http://dx.doi.org/10.1016/S0360-3199(00)00125-7

[5] Angenent, L.T, Karim, K., Al-Dahhan, K., Wrenn, B.A. and Espinosa, R.D. (2004) Production of bioenergy and biochemicals from industrial and agricultural wastewater. Trends in Biotechnology, 22, 476-785. http://dx.doi.org/10.1016/j.tibtech.2004.07.001

[6] Argun, H. and Kargi, F. (2009) Effects of sludge pretreatment method on bio-hydrogen production by dark fermentation of waste ground wheat. International Journal of Hydrogen Energy, 34, 8543-8548. http://dx.doi.org/10.1016/j.ijhydene.2009.08.049

[7] O-Thong, S., Prasertsan, P., Intrasungkha, N., Dhamwichukorn, S. and Birkeland, N.K. (2007) Improvement of biohydrogen production and pollution reduction from palm oil mill effluent with nutrient supplementation at thermophilic condition using an anaerobic sequencing batch reactor. Enzyme and Microbial Technology, 41, 583590.http://dx.doi.org/10.1016/j.enzmictec.2007.05.002

[8] Schauer-Gimenez, E.A., Zitomer, D.H., Maki, J.S. and Struble, A.C. (2010) Bioaugmentation for improved recovery of anaerobic digesters after toxicant exposure. Water Research, 44, 3555-3564.

http://dx.doi.org/10.1016/j.watres.2010.03.037

[9] Van Limbergen, H., Top, E.M. and Verstraete, W. (1998) Bioaugmentation in activated sludge: Current features and future perspectives. Applied Microbiology and Biotechnology, 50, 16-23.

http://dx.doi.org/10.1007/s002530051250

[10] Saravanane, R., Murthy, D.V.S. and Krishnaiah, K. (2001) Bioaugmentation and anaerobic treatment of pharmaceutical effluent in fluidized bed reactor. Journal of Environmental Science and Health, 35, 779-791. http://dx.doi.org/10.1016/S0960-8524(00)00121-8

[11] Arriaga, S., Rosas, I., Alatriste-Mondragón, F. and Razo-Flores, E. (2011) Continuous production of hydrogen from oat straw hydrolysate in a biotricklingfilter . International Journal of Hydrogen Energy, 36, 3442-3449. http://dx.doi.org/10.1016/j.ijhydene.2010.12.019

[12] Angelidaki, I. and Sanders, W. (2004) Assessment of the anaerobic biodegradability of macropollutants. Reviews in Environmental Science and Biotechnology, 3, 117-129. http://dx.doi.10.1007/s11157-004-2502-3

[13] Hasyim, R., Imai, T., Reungsang, A. and O-Thong, S. (2011) Extreme-thermophilic biohydrogen production by an anaerobic heat treated digested sewage sludge culture. International Journal of Hydrogen Energy, 36, 87278734.http://dx.doi.org/10.1016/j.ijhydene.2010.06.079

[14] O-Thong, S., Hniman, A., Prasertsan, P. and Imai, T. (2011) Biohydrogen production from cassava starch processing wastewater by thermophilic mixed cultures. International Journal of Hydrogen Energy, 36, 3409-3416. http://dx.doi.org/10.1016/j.ijhydene.2010.12.053

[15] APHA. (1995) Standard methods for the examination of water and waste water. 19th Edition, Edited by American Public Health Association, Washington DC.

[16] Morris, D.L. (1984) Quantitative determination of carbohydrates with Dreywood's anthrone reagent. Science, 107, 254-255. http://dx.doi.org/10.1126/science.107.2775.254

[17] Kotsopoulos, T.A., Fotidis, I.A., Tsolakis. N. and Martzopoulos, G.G. (2009) Biohydrogen production from pig slurry in a CSTR reactor system with mixed cultures under hyper-thermophilic temperature $\left(70^{\circ} \mathrm{C}\right)$. Biomass and Bioenergy, 33, 1168-1174. http://dx.doi.org/10.1016/j.biombioe.2009.05.001

[18] Shina, H.S., Younb, J.H. and Kima, S.H. (2004) Hydrogen production from food waste in anaerobic mesophilic and thermophilic acidogenesis. International Journal of Hydrogen Energy, 29, 1355-1363. http://dx.doi.org/10.1016/j.ijhydene.2003.09.011

[19] Rasdi, Z., Mumtaz, T., Rahman, N.A.A. and Hassan, M.A. (2012) Kinetic analysis of biohydrogen production from anaerobically treated POME in bioreactor under optimized condition. International Journal of Hydrogen Energy, 37, 17724-17730. 
http://dx.doi.org/10.1016/j.ijhydene.2012.08.095

[20] van Niel, E.W., Claassen, P.A. and Stams, A.J. (2003) Substrate and product inhibition of hydrogen production by the extreme thermophile, Caldicellulosiruptor saccharolyticus. Biotechnology and Bioengineering, 81, 254-262. http://dx.doi.org/10.1002/bit.10463 